\title{
Designing an E-Portfolio as a Storage, Workspace and Showcase for Social Sciences and Humanities in Higher Education Institutions (HEIs)
}

\author{
Syamsul Nor Azlan Mohamad ${ }^{1}$, Mohamed Amin Embi ${ }^{2} \&$ Norazah Mohd Nordin ${ }^{2}$ \\ ${ }^{1}$ Department of Teaching \& Learning Innovation, Faculty of Education, Universiti Teknologi MARA, Malaysia \\ ${ }^{2}$ Faculty of Education, Universiti Kebangsaan Malaysia, Malaysia \\ Correspondence: Syamsul Nor Azlan Mohamad, Department of Teaching \& Learning Innovation, Faculty of \\ Education, Universiti Teknologi MARA, Malaysia. E-mail: snazlan@siswa.ukm.edu.my
}

\author{
Received: February 29, 2016 Accepted: March 10, 2016 Online Published: April 19, 2016 \\ doi:10.5539/ass.v12n5p185 URL: http://dx.doi.org/10.5539/ass.v12n5p185
}

\begin{abstract}
The present articles introduce the e-Portfolio as a storage, workspace and showcase to support teaching and learning in higher education institutions (HEIs). Thus, the mix-method approach was implemented on determining important elements of e-Portfolio as a storage, workspace and showcase for a social sciences and humanities context. This study implemented thematic analysis and Fuzzy Delphi Method to obtain the result. Therefore, 25 experts in instructional technology was participated in the process of the making a decision. As resulted, this study highlighted the fundamental of e-Portfolio consists; workspace, storage and showcase. Eventually, the instructional designer will understand and strategies on how to develop an effective e-Portfolio as learning support tool to enhance the learning experience between facilitator and learner.
\end{abstract}

Keywords: e-learning, e-portfolio, workspace, storage, showcase, science social and humanities, higher education, design and developmental research, fuzzy delphi method

\section{Introduction}

There are many researchers who advocate the use of portfolios in higher education institutions for both learners and facilitators. However, very limited empirical research gives its due focus on the development of portfolios than their effects on student learning. This has resulted in the invention of e-Portfolio with the ' $E$ ' as a new concept which suggests online environments with electronic tools can be used to develop and present a self or group portfolios. This invention offers the creation, management, maintenance, and presentation of electronic portfolios. E-Portfolio can be used as a personal and lifelong content-management system for collecting, reflecting, selecting, and presenting learning outcomes, and other professional accomplishments.

In recent years, there has been a growing interest in the use of e-portfolio for assessing the achievements of student learning (Drost, Hanson, Molstad, Peake, \& Newman, 2008). In 1990s, the e-Portfolios have been used by students in disciplines such as art and architecture as a means of collating evidence of learning (Harun \& Cetinkaya, 2007). With the development of internet and technology, the use of e-Portfolio has significantly sprouted with higher education institutions (Juwah, Macfarlane-Dick, Matthew, Nicol, Ros, \& Smith, 2004). At this juncture, there are two reasons why e-Portfolio has been chosen as the subject for this research. The first reason is influenced by the potentials of constructive approach to education which emphasizes learning by experience (Beck, Livne, \& Bear, 2005; Klenowski, Askew, \& Carnell, 2006; Lynch \& Purnawarman, 2004). The second aspect is the prospect that computer technology holds in education to support the facilitators and learners (Meeus, Questier, \& Derks, 2006).

The greatest attraction of e-Portfolios is that the students develop personalities, growth, and autonomy in learning (Batson, 2002). This is topped with the offer for better holistic representation of students' understanding supported with evidence-based rather than the traditional one-time assessment such as tests, quizzes or exam papers. In addition to support learning experience, the potentials of technology is undeniably palpable because it can hold a variety of artefacts or evidence. Consequently, students are provided with the choice to choose the method of submission, to select and explain the standards of the evidence in the documents. This in turn will assist them to better reflect upon their own learning allowing them to be the architect of their own learning (De 
Rijdt, Tiquet, Dochy, \& Devolder, 2006; Sturrock \& Early, 2007; Syamsul Nor Azlan, 2015; Thomas, Lamson, \& King, 2001).

However, a variety of problems and issues have come to the attention of researchers and practitioners with the use of portfolios in a learning environment such as the lack of well-defined guidelines and a clear structure (Smith \& Tillema, 2003). This is feared to cause confusion and anxiety among students with regard to the scope and value of the e-Portfolio (Darling, 2001). Past researchers have stated that without proper guideline and being student-driven can lead the students to be lacking in self-directedness and motivation (Zeichner \& Wray, 2001). Students need guidance and support to showcase their concepts, understanding, and skills to fulfill the learning outcomes (Smith \& Tillema, 2003) which require a lot of time on the part of the facilitators and the students (Wade \& Yarbrough, 1996).

Despite all the concerns raised, the researchers have agreed that students' e-Portfolio have a wide range of potentials that need to be explored and considered. Sturrock and Early (2007) explained that the use of e-Portfolio is capable as a place to manage visual art and design projects, researching, relating knowledge and becoming committed to on-going professional development and higher-order thinking, as they learn to collect, display, articulate, evaluate, and communicate their ideas. There is a strong support for the notion that e-Portfolio learning environments can be effectively used to support constructivism and transformative learning (Reushle, 2005; Wilson, 2004) and the advantages may be limitless. The building of content knowledge and skills was documented as a referral for future references. Eventually, the students will be equipped with specific learning domain and experience that may design their potentials as professionals or experts in their respective areas.

\section{Literature Review}

E-Portfolio designed as a learning support tool in teaching and learning process (Wade, 2005; Barrett, 2007) with Attwell (2005) provide prior support that e-Portfolio may be used not only for one generic approach but applicable in multiple or different pedagogic strategies to support teaching and learning. One such use is a developmental e-portfolio that is meant to record things that learners have done over a period of time and may be directly tied to learner outcomes or rubrics (Omidvar, Jaryani, \& Abdul, 2011). Paulson, Paulson and Meyer (1991) described that the creation of e-Portfolio as follows:

A portfolio tells a story. It is the story of knowing. Knowing about things... Knowing oneself... Knowing an audience... Portfolios are students' own stories of what they know, why they believe they know it, and why others should be of the same opinion. A portfolio is opinion backed by fact... Students prove what they know with samples of their work. (1991, p. 2)

Research has proven that when students use portfolios, they will become more responsive to their strengths and limitations while learning to improve their ways (Zellers \& Mudrey, 2007). In Malaysia context, the portfolio is used as an evidence to evaluate the level of specific cognitive ability and psychomotor skills. However, a paper-based portfolio is limited as a storage only. Due to prior limitation, the e-Portfolio has outperformed and provided a better means for learners. It is also aligned with the Ministry of Education (2011) encouragement for HEIs in Malaysia to expand the implementation of online tools for learning.

Various definitions were produced for e-Portfolio from earlier researches. Abrami and Barrett (2005) defined e-Portfolio as a digital storage that has a capability of storing and organizing multimedia materials on a server or cloud, whether locally or on the Internet. Since they are web-based, they provide remote access that encourage students to engage with their learning anywhere and at any time. In contrast, Heinrich (2007) emphasized that e-portfolio is much more than just a collection of students' work. He is supported by Barrett, Garthwait and Verrill (2003) and also Gülbahar and Tinmaz (2006) that e-Portfolio also can work as a workspace and showcase.

Meeus, Questier and Derks (2006) explained that an e-Portfolio is a platform to demonstrate, exhibit or show a person's life achievements and experiences (Rodriguez-Donaire \& Garcia, 2011; Zheng et al., 2009). Therefore, e-Portfolio as a workspace represents the developmental process of the learners. Barrett (2007b) re-conceptualized the meaning of e-Portfolio by stated, it should be prioritized on learning reflection and achievement to enable learners to substitute the ideas and feedbacks among peers (Lorenzo \& Ittleson, 2005).

The scaffold between peers as a result of learning domain is to reflect the relationship of higher-order thinking skills and learning context (Jones \& Lau, 2009). While learners engage in the production of their works, they are made aware of the integration of the process and how they fit into the content of the e-Portfolio (Zimmerman, 2009). Meanwhile, peer engagement allows reflection (Eynon, 2012) by giving feedback and collaborating on each other's work on higher-order thinking throughout the meaningful process (Wade \& Abrami 2005). The primary role of the facilitator at this level is to provide formative feedback on the students work so that they can 
recognize opportunities for improvement.

In recent years, higher education institutions in Malaysia have started to use e-portfolio as a showcase of students' talents and works to aid curricular assessment and career development (Mobarhan, 2002; Rahim, 2015) The e-Portfolio as a showcase enables learner to get started on the process and learn the value of completing a portfolio. It is so significant with the current global economic crisis that HEIs' use e-Portfolio to show their graduates' performance and competency development (Wu, 2011). As an example of the use of e-portfolio for the showcase, Stevens (2008) introduced the South West Opportunities for Older People (SWOOP) program to showcase and enhance the employability of the elderly. These e-Portfolios will be useful when applying for employment, both for work experience placements and upon graduation.

In this study, Social Sciences and Humanities consists five faculties such Faculty of Education, Faculty of Art and Design, Faculty of Music, Faculty of Mass Media and Communication and lastly Faculty of Film, Theatre and Animation who practicing portfolio as an evidence-based assessment as to fulfil the Malaysian Qualification Agency (MQA) requirement. Thus, MQA has indicated that $40 \%-70 \%$ of evaluation is an evidence-based assessment to measure the learning outcome and competencies of each learner. However, some of the setbacks with this traditional way of assembling learners' works in developing a portfolio involve tedious documenting process, restricted space, and take up more time to assess their performances. It is also worthy to signify the challenge that awaits portfolio assessors in facilitating learners in a crowded classroom while attempting to give focus in certain needs or specific skills as stated in the instructional objectives (Birgin 2007). Hence, it is timely that e-Portfolio take its place and fulfil the needs in learning while overcoming some of the constraints mentioned.

So, the researcher suggests that there is a necessity to have an e-Portfolio as a medium to sort all of the problematic issues including storage, workspace and showcase (Becta, 2007; Blaikie, Schonau, \& Steers, 2004; Fitch, Peet, Reed, \& Tolman, 2008). The possibilities of e-Portfolio being merged with cloud computing to solve the pertaining issues such as a storage as well as handling and controlling will extend teaching and learning to another level. In the $21^{\text {st }}$ century, e-learning is a convenient platform in extending e-Portfolio usage by utilizing web-based to another level of accessibility. This study highlighted the fundamental or basic elements includes in e-Portfolio consists the function as workspace, storage and showcase. Eventually, the instructional designer will understand and strategies on how to develop an effective learning support tool to enhance the learning experience between facilitator and learner. The interaction and engagement is important to save the purpose and success of e-Portfolio.

\section{Methodology}

In this study, Fuzzy Delphi Method (FDM) has been proposed to allows experts to fully express their opinions. Interestingly, it also takes into account the ambiguity that cannot be avoided during the study. This method does not misinterpret the original experts' opinion and reveal their real reactions. Following are the steps of the Fuzzy Delphi Method:

\subsection{Round One (1): Issues and Interview Protocol}

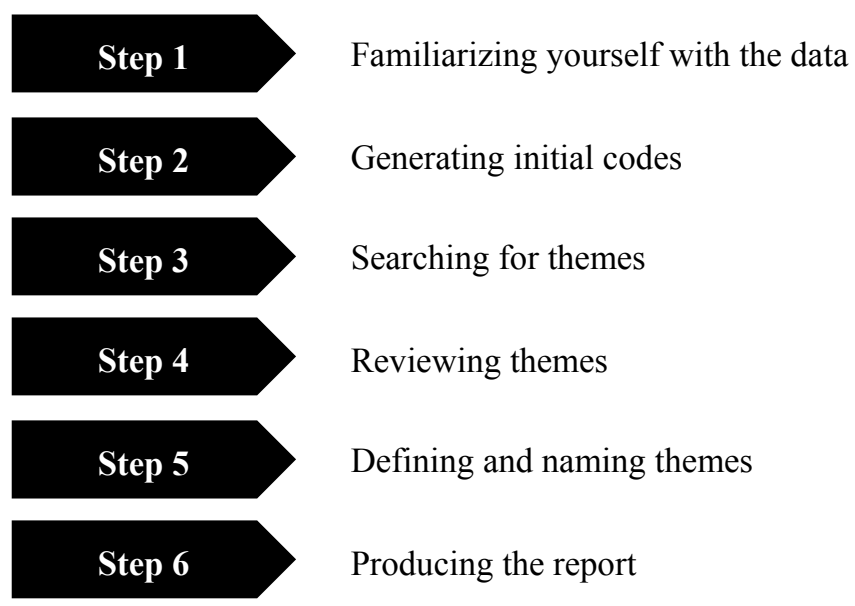

Figure 1. Six steps in thematic analysis 
The first phase of data collection involved semi-structured interviews with experts in e-Portfolio enlisted at the different universities. Thematic analysis was executed to determine whether they were sharing experiences or simply pre-digested theoretical knowledge. The interview protocols were read independently in order to obtain intuitive grasp of the description. Statements made by each learners which are recognizable aspects of their experiences were retrieved and listed verbatim. The researcher collapsed the participants' statements into emergent themes and simultaneously distinguished possible linkages and relationships. In doing the analysis, the researcher referred to a few method or steps proposed by other researchers in research methodology. Braun, V. and Clarke (2006) has proposed six steps in thematic analysis. The steps are shown in Figure 1.

\subsection{Round Two (2): Fuzzy Delphi Analysis}

Fuzzy Delphi was employed bases on group thinking of the qualified experts as mentioned in (Syamsul, Mohamed Amin Embi, \& Norazah 2015; Siraj, 2012) in their previous works. The "E-Portfolio Consensus Survey" was developed based on the emerging themes from the experts. There are about 25 experts in instructional technology involved and responses the survey.

\section{Findings and Discussion}

These constructs were divided into three (3) sub-constructs which are level 1 is storage ( 7 items), level 2 is workspace (6 items) and level 3 is showcase (4 items). The item analysis is described in the subsequent sub-sections.

\subsection{E-Portfolio as a Workspace}

Here is the threshold (d) values, expert consensus percentage and defuzzification by items can be referred to Table 1.

Table 1. Threshold values (d), expert consensus percentage, defuzzification and ranking by e-portfolio as a workspace items

\begin{tabular}{|c|c|c|c|c|c|c|c|}
\hline Items & A1.1 & A1.2 & A1.3 & A1.4 & A1.5 & A1.6 & A1.7 \\
\hline Description & $\begin{array}{c}\text { displays } \\
\text { digital } \\
\text { documents }\end{array}$ & $\begin{array}{c}\text { displays } \\
\text { digital } \\
\text { work } \\
\text { format }\end{array}$ & $\begin{array}{l}\text { demonstration } \\
\text { of } \\
\text { projects/tasks } \\
\text { or assignments }\end{array}$ & $\begin{array}{l}\text { provides } \\
\text { evidence } \\
\text { for } \\
\text { learning. }\end{array}$ & $\begin{array}{l}\text { shows } \\
\text { resources } \\
\text { of } \\
\text { learning }\end{array}$ & $\begin{array}{l}\text { report that } \\
\text { describes the } \\
\text { success of } \\
\text { the work or } \\
\text { project }\end{array}$ & $\begin{array}{c}\text { shared } \\
\text { with } \\
\text { anyone } \\
\text { within and } \\
\text { outside }\end{array}$ \\
\hline $\begin{array}{l}\text { Items } \\
\mathrm{d} \leq 0.2\end{array}$ & 0.093 & 0.131 & 0.191 & 0.115 & 0.172 & 0.172 & 0.184 \\
\hline $\begin{array}{c}\text { Construct } \\
\mathrm{d} \leq 0.2\end{array}$ & & & & 0.123 & & & \\
\hline \multirow[t]{2}{*}{$\% \mathrm{~d} \leq 0.2$} & $100 \%$ & $100 \%$ & $88 \%$ & $100 \%$ & $88 \%$ & $94 \%$ & $94 \%$ \\
\hline & \multicolumn{7}{|c|}{ Expert Group Consensus Percentage $\% \mathrm{~d} \leq 0.2(95 \%)$} \\
\hline Defuzzification & 0.763 & 0.738 & 0.700 & 0.750 & 0.650 & 0.688 & 0.713 \\
\hline Ranking & 1 & 3 & 5 & 2 & 7 & 6 & 4 \\
\hline
\end{tabular}

- Rules 1: No items exceed the threshold value (d) $=0.2$. (Cheng \& Lin, 2002)

- Rules 2: Second rules in fuzzy delphi also accepted whereas percentage consensus of expert more than $75 \%$ expert agreed. (Chu \& Hwang, 2008; Murray \& Hammons, 1995)

- Rules 3: Defuzzification values showed each items reach above $\alpha$-cut $=0.5$.

As can see in Table 1, the item analysis explained the constructs achieved the experts' consensus. The items were arranged according to priority and ranking-based. The digital documents had the highest consensus expert score 0.763 and resources learning score was the lowest score with 0.650. Experts agreed that e-Portfolio is a place to displays digital documents $(0.763)$, evidence for learning $(0.750)$ and converting into digital work format $(0.738)$. The e-Portfolio whereas the students shared $(0.713)$, demonstrate $(0.700)$, progress report $(0.688)$ and show resources. 
E-Portfolio as a Workspace: The learners keep learning using e-Portfolio as a workspace and reflect their learning as represented in the artifacts or artworks stored in the digital archieve. The workspace provides learners to update and edit the digital artefacts that are stored in a virtual space or cloud. Therefore, the primary role of the artifacts or artworks is to promote self directed learning among learners and motivate them to collect and select the best quality of materials to showcase among their peers.

This level of reflection is more progressive and thinking forward to create a dynamic relationship among facilitators, learners and the body of knowledge. The formative and summative assessment is a key features to evaluate and diagnose the learner's performance time to time for room of improvement. The facilitator will set up the lesson structure for the learners to reflect provided with feedback, prompt and hints of the task given. This reflective learning allows the learners to scaffold with facilitator and peers. The learners reflect on the materials on the specific goals and outcome based on the supported evidence and documents.

E-Portfolio may foist some challenging experiences to students while they documenting their progress that subsequently becomes the emergence of the learners' portfolio narratives. Bogossian, F. E., and Kellett (2010) rises an issues that can impede the use of e-portfolios as workspace include: time constraints, issues related to privacy, colleagues' views of the value of reflection, and a lack of motivation to use the platforms.

Similarly, Smith, E., and Mills (2009) studies highlighted some disadvantages of e-Portfolios viewed by engineering students were that they found the technology frustrating, time consuming, and effective use depended ultimately on the student's computer literacy skills and how much they perceived they could benefit from the platform There is a need for an investigation into more effective ways for e-Portfolios to be used to promote and integrate higher-order thinking skills. This highlighted the importance of generic or specific pedagogical issues underpinning facilitation of higher-order thinking skills and in the use of e-Portfolios.

One of the effective strategies to facilitate higher-order thinking skills are with scaffolding between peers and facilitator. As a resulted, Jones and Lau (2009) has proven that the scaffolding has a significant effect between the higher-order thinking skills and e-Portfolio learning context. It occur when learners engage in the production of their works, they are made aware of the integration of the process and how they fit into the content of the e-Portfolio (Zimmerman, 2009). Meanwhile, peer collaboration allows reflection by giving feedback and collaborating on each other's work on higher-order thinking throughout the meaningful process (Eynon, 2012; Wade \& Abrami, 2005). The primary role of the facilitator is to provide an effective strategy to the students work with e-Portfolio and had an opportunities improve their knowledge and skills

\subsection{E-Portfolio as a Storage}

Table 2 shows the threshold (d) values, expert consensus percentage and defuzzification by items as follows

Table 2. Threshold values (d), expert consensus percentage, defuzzification and ranking by e-portfolio as a storage items

\begin{tabular}{ccccccc}
\hline Items & A2.1 & A2.2 & A2.3 & A2.4 & A2.5 & A2.6 \\
\hline Description & $\begin{array}{c}\text { systematic } \\
\text { storage of } \\
\text { different } \\
\text { types of } \\
\text { media }\end{array}$ & $\begin{array}{c}\text { allows } \\
\text { creation } \\
\text { of } \\
\text { content. }\end{array}$ & $\begin{array}{c}\text { allows } \\
\text { editing of } \\
\text { content. }\end{array}$ & $\begin{array}{c}\text { allows } \\
\text { updating } \\
\text { of } \\
\text { content. }\end{array}$ & $\begin{array}{c}\text { is a collection of } \\
\text { digital artifact stored } \\
\text { in a virtual space or } \\
\text { cloud. }\end{array}$ & $\begin{array}{c}\text { function as a file } \\
\text { repository to } \\
\text { backup or } \\
\text { import/export } \\
\text { different media. }\end{array}$ \\
\hline $\begin{array}{c}\text { Items } \\
\mathrm{d} \leq 0.2\end{array}$ & 0.193 & 0.215 & 0.184 & 0.131 & 0.210 & 0.172 \\
\hline $\begin{array}{c}\text { Construct } \\
\mathrm{d} \leq 0.2\end{array}$ & $88 \%$ & $81 \%$ & $88 \%$ & $100 \%$ & $88 \%$ & \\
\hline$\% \mathrm{~d} \leq 0.2$ & \multicolumn{7}{c}{0.184} & \\
\hline $\begin{array}{c}\text { Expert Group Consensus Percentage } \% \mathrm{~d} \leq 0.2(90 \%) \\
\text { on }\end{array}$ & 0.688 & 0.675 & 0.713 & 0.738 & 0.700 & 3 \\
\hline Ranking & 4 & 5 & 2 & 1 & 3 & 0.700 \\
\hline
\end{tabular}


- Rules 1: Items A2.2 and A2.5 exceed the threshold value (d) =0.2. (Cheng \& Lin, 2002).

- Rules 2: Second rules in fuzzy delphi also accepted wheres percentage consensues of expert more than $75 \%$ expert agreed. (Chu \& Hwang, 2008; Murray \& Hammons, 1995).

- Rules 3: Defuzzification values showed each items reach above $\alpha$-cut $=0.5$.

As mentioned, the item analysis explained the constructs which gained the experts' consensus. The items were arranged according to priority and ranking-based. The updating content had the highest expert consensus score 0.738 while content creation score was the lowest score with 0.675 . The items analysis showed, using e-Portfolio allows students to updating (0.738), editing ( 0.713$)$, virtual space or cloud $(0.700)$, backup or import/export $(0.700)$, systematic storage $(0.675)$ and also allows content creation $(0.675)$.

E-Portfolio as a Storage: Various definitions were produced for e-Portfolio from earlier researches. Abrami and Barrett (2005) defined e-Portfolio as a digital storage that has a capability of storing and organizing multimedia materials includes text, graphics, sound, and video on a server or cloud, whether locally or on the Internet.

In contrary, C. C. Chang (2002) has compared traditional learning relies on man-made data collection and a writing-centered learning process. It makes some difficulties in data storage, search, and management after long-term implementation have become problematic in developing and implementing portfolio. Therefore, electronic form is a solution to ensure it can be used for a long-term implementation due to the capability store on server or cloud provided with a higher protection.

The basic level of creating e-Portfolio is the collection of artifacts or artworks stored virtually in the web 2.0 system and tools. At this stage, the facilitator asks the students to stores by create, update, edit and share the artifacts or artworks in a set of folder on the platform prepared by the researcher. This basic activity was designated to keep the evidence-based safely compared than the traditional paper-based e-Portfolio. It is also capable to include progress reports and resources on learning either to use within or outside of the classroom.

\subsection{E-Portfolio as a Showcase}

Table 3 display the threshold (d) values for the expert consensus percentage and defuzzification by items as follows.

Table 3. Threshold values (d), expert consensus percentage, defuzzification and ranking by e-portfolio as a showcase items

\begin{tabular}{|c|c|c|c|c|}
\hline Items & A3.1 & A3.2 & A 3.3 & A3.4 \\
\hline Description & $\begin{array}{c}\text { can be accessed by anyone } \\
\text { or everyone, at anywhere } \\
\text { and anytime. }\end{array}$ & $\begin{array}{c}\text { showcases students' } \\
\text { works. }\end{array}$ & $\begin{array}{l}\text { showcases } \\
\text { students' talents. }\end{array}$ & $\begin{array}{l}\text { can be used to } \\
\text { prepare for job } \\
\text { hunting. }\end{array}$ \\
\hline $\begin{array}{c}\text { Items } \\
\mathrm{d} \leq 0.2\end{array}$ & 0.172 & 0.143 & 0.115 & 0.172 \\
\hline $\begin{array}{c}\text { Construct } \\
\mathrm{d} \leq 0.2\end{array}$ & \multicolumn{4}{|c|}{0.150} \\
\hline$\% \mathrm{~d} \leq 0.2$ & $88 \%$ & $100 \%$ & $100 \%$ & $88 \%$ \\
\hline & \multicolumn{4}{|c|}{ Expert Group Consensus Percentage \% $d \leq 0.2(94 \%)$} \\
\hline Defuzzification & 0.725 & 0.725 & 0.750 & 0.725 \\
\hline Ranking & 2 & 2 & 1 & 2 \\
\hline
\end{tabular}

- Rules 1: No items exceed the threshold value $(d)=0.2$. (Cheng \& Lin, 2002).

- Rules 2: Second rules in fuzzy delphi also accepted whereas percentage consensus of expert more than $75 \%$ expert agreed. (Chu \& Hwang, 2008; Murray \& Hammons, 1995).

- Rules 3: Defuzzification values showed each items reach above $\alpha$-cut $=0.5$.

As mentioned, the item analysis explained that the constructs had gained the consensus from the experts. The items were arranged according to priority and ranking-based. Showcasing students' talents had the highest consensus expert score of 0.75 . Then, Level 3 is a showcase in which the e-Portfolio exhibits students' talent and 
works that can be accessed by anyone, anywhere at any time, and as preparation for their future job hunt. Experts agreed e-Portfolio showcase students talent $(0.750)$, students works $(0.700)$, accessible for anyone $(0.700)$ and also as a preparation for job hunting (0.700).

E-Portfolio as a Showcase: The purposes of the e-Portfolio is a not only for learning but showcasing learner collected of their work and reflected upon their work, which are expected to provide them with directions for lifelong learning. Learners were mentored to extract relevant evidence and write reflections to showcase their skills, understanding and learning.

At level 3, the e-Portfolio requires the learners to organize and display the artifacts or artworks around the set of learning goals and outcome. The presentation is develop using e-Portfolio tools. Hence, the technology of e-Portfolio offers a variety of tool to enhanced learning experience and allows facilitator and learners stay connected all the time and benefit the use of technology in virtual classroom. Thus, the e-Portfolio allows the students to showcase their talent and artworks for future use especially relate to continuous professional development such as job preparation, lifelong learning and self evaluation.

In recent years, higher education institutions in Malaysia have started to use e-portfolio as a showcase of students' talents and works to aid curricular assessment and career development (Mobarhan, 2002; Rahim, 2015) The e-Portfolio as a showcase enables learner to get started on the process and learn the value of completing a portfolio. It is so significant with the current global economic crisis that HEIs' use e-Portfolio to show their graduates' performance and competency development (Wu, 2011). As an example of the use of e-portfolio for the showcase, Stevens (2008) introduced the South West Opportunities for Older People (SWOOP) program to showcase and enhance the employability of the elderly. These e-Portfolios will be useful when applying for employment, both for work experience placements and upon graduation.

In addition, Tillema (2000), for one, agreed that the importance of e-Portfolio is not only the end product but the process of constructing individual learning. Besides that, experts suggested the faculty also need to ensure the availability of computers and wireless connection to accommodate the number of learners who are using the e-Portfolio in the course. Universities throughout Malaysia intent to adopt blended learning in attempts to diversify the ways of teaching and learning. Therefore, accommodating for better infrastructure will benefit both learners and facilitators towards experiencing the best quality of teaching and learning.

\section{Conclusion}

The definitions of e-Portfolio need to be revised according to the purpose of the study. The experts agreed that e-Portfolio was divided into three levels of functions: Level 1 storage, Level 2 workspace and Level 3 showcase. Level 1 is considered as storage to display digital documents, provide evidence for learning and then to be converted into the digital format. The e-storage also works as a sharing tool to demonstrate the leaners' projects/tasks or assignments. It is also capable to include progress reports and resources on learning either to use within or outside of the classroom. Thus, Level 2 is a workspace that allows learners to update and edit the digital artefacts that are stored in a virtual space or cloud. This also works as a file repository to backup or import/export different media with other types of media and allows content creation. Then, Level 3 is a showcase in which the e-Portfolio exhibits students' talent and works that can be accessed by anyone, anywhere at any time, and as preparation for their future job hunt.

\section{References}

Abrami, P., \& Barrett, H. (2005). Directions for research and development on electronic portfolios. Canadian Journal of Learning and Technology, 31(3), 1-15.

Anne Wade, P. C. A., \& J. S. (2005). An Electronic Portfolio to Support Learning. Canadian Journal of Learning and Technology, 31(3), 1-11.

Attwell, G. (2005). Portfolios, social software and non formal learning.

Barrett, H. C. (2007). Researching Electronic Portfolios and Learner Engagement: The REFLECT Initiative. Journal of Adolescent \& Adult Literacy, 50(6), 436-449. http://dx.doi.org/10.1598/JAAL.50.6.2

Barrett, H. C. (2009). Balancing the Two Faces of E-Portfolios.

Batson, T. (2002). The Electronic Portfolio Boom: What's it All About? Syllabus, 16(5), 1-5.

Beck, R. J., Livne, N. L., \& Bear, S. L. (2005). Teachers' self assessmentof the effects of formative and summative electronic portfolios on professional development. European Journal of Teacher Education, 28(3), 221-244. http://dx.doi.org/10.1080/02619760500268733 
Becta. (2007). Harnessing technology review 2007. Progress and impact of technology in education.

Bİrgİn, O. (2007). The Use of Portfolio to Assess Student's Performance. Turkish Science Education, 4(2), $75-90$.

Blaikie, F., Schonau, D., \& Steers, J. (2004). Preparing for portfolio assessment in art and design: A study of the opinions and experiences of exiting secondary school students in Canda, England and The Netherlands. International Journal of Art and Design Education, 23(3), 302-315. http://dx.doi.org/10.1111/j.1476-8070. 2004.00409.x

Bogossian, F. E., \& Kellett, S. E. M. (2010). Barriers to electronic portfolio access in the clinical setting. Nurse Education Today. http://dx.doi.org/10.1016/j.nedt.2010.02.003

Braun, V., \& Clarke, V. (2006). Using thematic analysis in psychology. Qualitative Research in Psychology, 3(2), 77-101. http://dx.doi.org/10.1191/1478088706qp063oa

Chang, C. C. (2002). Building a Web-based learning portfolio for authentic assessment. In Conference Computer Education (pp. 129-133). http://dx.doi.org/10.1109/CIE.2002.1185883

Cheng, C. H., \& Lin. (2002). Evaluating the best main battle tank using fuzzy decision theory with linguistic criteria evaluation. European Journal of Operational Research 2002, 142(1), 74-86. http://dx.doi.org/10. 1016/s0377-2217(01)00280-6

Chu \& Hwang. (2008). A Delphi-based approach to developing expert systems with the cooperation of multiple experts. Expert Systems with Applications, 34(28), 26-40.

Darling, L. F. (2001). Portfolio as practice: The narratives of emerging teachers. Teaching and Teacher Education, 17(1), 107-121. http://dx.doi.org/10.1016/S0742-051X(00)00041-X

De Rijdt, C., Tiquet, E., Dochy, F., \& Devolder, M. (2006). Teaching portfolios in higher education and their effects: An explorative study. Teaching and Teacher Education, 22(8), 1084-1093. http://dx.doi.org/10. 1016/j.tate.2006.07.002

Drost, D., Hanson, L., Molstad, C., Peake, L., \& Newman, E. (2008). Outcome assessment of a management program using a portfolio approach: Lessons learned. American Journal of Business Education, Fourth Quarter. American Journal of Business Education, Fourth Quarter, 1(2), 105-111.

Eynon, J. E. C., \& B. (2012). Measuring Student Progress with E-portfolios. AAC\&U, 6-8.

Fitch, D., Peet, M., Reed, B., \& Tolman, R. (2008). The use of ePortfolios in evaluating the curriculum and student learning. Journal of Social Work Education, 44(3), 37-54. http://dx.doi.org/10.5175/JSWE.2008. 200700010

Garthwait, A., \& Verrill, J. (2003). E-Portfolios: Documenting students progress. Science and Children, 41(6), 22-27.

Gülbahar, Y., \& Tinmaz, H. (2006). Implementing Project-Based Learning And E-Portfolio Assessment In an Undergraduate Course. Journal of Research on Technology in Education, 309-327. http://dx.doi.org/10. $1080 / 15391523.2006 .10782462$

Harun, Y., \& Cetinkaya, B. (2007). Using an online portfolio course in assessing students' work. Turkish Online Journal of Educational Technology, 6(4), 1-6.

Heinrich, B. R. (2007). Preparation for lifelong learning using ePortfolis. European Journal of Enggineering Education, 32(6), 653-663. http://dx.doi.org/10.1080/03043790701520602

Jones, N., \& Lau, A. (2009). E-learning - a change agent for education? Journal of Applied Research in Higher Education, 1(1), 40-48. http://dx.doi.org/10.1108/17581184200900004

Juwah, C., Macfarlane-Dick, D., Matthew, B., Nicol, D., Ros, D., \& Smith, B. (2004). Enhancing student learning through effective formative feedback.

Klenowski, V., Askew, S., \& Carnell, E. (2006). Portfolios for learning, assessment and professional development in higher education. Assessment and Evaluation in Higher Education, 31(3), 267-286. http://dx.doi.org/10.1080/02602930500352816

Lorenzo, G., \& Ittleson, J. (2005). Demonstrating and assessing student learning with eportfolios. EDUCAUSE-ELI Paper 3, 2005.

Lynch, L. L., \& Purnawarman, P. (2004). Electronic portfolio assessments in US educational and instructional 
technology programs: Are they supporting teacher education? TechTrends, 48(1), 50-56. http://dx.doi.org/10.1007/BF02784865

Meeus, W., Questier, F., \& Derks, T. (2006). Open source eportfolio: Development and implementation of an institution-wide electronic portfolio platform for students. Educational Media International, 43(2), 133-145. http://dx.doi.org/10.1080/09523980600641148

Mobarhan, R. (2002). Electronic Portfolios Acceptance and Use in Higher Educations: A Systematic Review, (1990).

Murry, J. W., \& Hammons, J. O. (1995). Delphi: A versatile methodology for conducting qualitative research. The Review of Higher Education, 18(4), 423-436.

Omidvar, G., Jaryani, F., \& Abdul, Z. Bin. (2011). E-Portfolio Role to Enhance Project Managers ' Competencies. 2nd International Conference on Construction and Project Management, 15, 200-204.

Paulson, F. L., Paulson, P. R., \& Meyer, C. (1991). What makes a portfolio a portfolio? Educational Leadership, 48(5), 60-63.

Rahim, M. B. (2015). E-portfolio indicator for competency assessment and virtual learning in Malaysia Skills Certification.TVET@Asia, (4),1-13.

Reushle, S. E. (2005). Inquiry into a transformative approach to professional development for online educators.

Rodriguez-Donaire, S., \& Amante Garcia, B. (2011). Web 2.0 as an e-portfolio tool. 2011 IEEE Global Engineering Education Conference (EDUCON), 397-403. http://dx.doi.org/10.1109/EDUCON.2011. 5773167

Siraj, S. (2012). Future Projection on Patriotism among School Students Using Delphi Technique. Creative Education, 3(26), 1053-1059. http://dx.doi.org/10.4236/ce.2012.326158

Smith, E., \& Mills, J. (2009). E-Portfolios and first year students - do we assume too much? In Australiasian Association for Engineering Education (AAEE).

Smith, K., \& Tillema, H. (2003). Clarifying different types of portfolio use. Assessment and Evaluation in Higher Education, 28(6), 625-648. http://dx.doi.org/10.1080/0260293032000130252

Stevens, H. (2008). The impact of e-portfolio development on the employability of adults aged 45 and over. Campus-Wide Information Systems, 25(4), 210.

Sturrock, D., \& Early, C. (2007). Mahara E-Portfolio system implementation case study. Retrieved from http://eduforge.org/docman/view.php/176/1516/AUT\%2

Syamsul Nor Azlan, M. A. E., \& N. M. N. (2015). Are Students Ready to Adopt E-Portfolio? Social Science and Humanities Context. Asian Social Science, 11(13), 269-275. http://dx.doi.org/10.5539/ass.v11n13p269

Syamsul Nor Azlan, M. A. E., \& N. M. N (2015). Determining e-Portfolio Elements in Learning Process Using Fuzzy Delphi Analysis. International Education Studies, 8(9), 171-176. http://dx.doi.org/10.5539/ies. v8n9p171

Thomas Lamson, S., \& King, A., K. R. (2001). Training teacher candidates to create web-based electronic professional portfolios. . Paper Presented at Central Missouri State University's Department of Curriculum and Instruction.

Tillema, H. H. (2000). Belief change towards self-directed learning in student teachers: immersion in practice or reflection on action. Teaching and Teacher Education, 16(5-6), 575-591. http://dx.doi.org/10.1016/S0742051X(00)00016-0

Wade, R. C., \& Yarbrough, D. B. (1996). Portfolios: A tool for reflective thinking in teacher education? Teaching and Teacher Education, 12(1), 63-79. http://dx.doi.org/10.1016/0742-051X(95)00022-C

Wade, A., \& Abrami, P. C. (2005). Canadian Journal of Learning and Technology / La revue canadienne de 1' apprentissage et de la. Canadian Journal of Learning and Technology, 31(3), 1-11.

Wilson, G. (2004). Online interaction impacts on learning: Teaching the teachers to teach online. Australasian Journal of Educational Technology, 20(1), 33-48.

Wu, S. (2011). The Benefits and Challenges Appraisal of Using E-portfolio for Taiwan 's Students and Guidance Teachers in Their Perspectives. ERAS Conference 2011 Empowering Educators as Researchers: Exploring Ideas and Enhancing Practices The, 1-12. 
Zeichner, K., \& Wray, S. (2001). The teaching portfolio in US teacher education programs: What we know and what we need to know. Teaching and Teacher Education, 17(5), 613-621. http://dx.doi.org/10.1016/S0742051X(01)00017-8

Zellers, M., \& Mudrey, R. R. (2007). Electronic portfolios and metacognition: A phenomenological examination of the implementation of e-portfolios from the instructors' perspective. International Journal of Instructional Media, 34(4), 419-430.

Zheng, W., Wang, F., Liu, Z., \& Zhao, C. (2009). Construction and Application of Instructional E-Portfolio System with Web2.0 and Google Services. 2009 First International Conference on Information Science and Engineering, 3265-3268. http://dx.doi.org/10.1109/ICISE.2009.423

Zimmerman, E. (2009). Reconceptualizing the Role of Creativity in Art Education Theory and Practice. Issues and Research, 50(4), 382-399.

\section{Copyrights}

Copyright for this article is retained by the author(s), with first publication rights granted to the journal.

This is an open-access article distributed under the terms and conditions of the Creative Commons Attribution license (http://creativecommons.org/licenses/by/3.0/). 